\title{
2
}

\section{War is their principal profession: On the frequency and causes of Maori warfare and migration, 1250-1850 CE}

\author{
Atholl Anderson
}

\section{Introduction}

In 1835 CE, Charles Darwin (1909:422) went walking in the Bay of Islands, northern New Zealand, and was 'surprised to find that almost every hill which I ascended, had been at some former time more or less fortified'. He then heard about the forts ( $p a$ in Maori) and fighting from the missionary William Williams, including a droll anecdote about a chief who started a war so as not to waste a barrel of deteriorating gunpowder. Darwin's (1909:423) comment that 'a more warlike race of inhabitants could not be found in any part of the world' was of a piece with most others that had preceded it. Abel Tasman in $1642 \mathrm{CE}$ 'found the natives to be of a malignant and murderous nature' (McNab 1914:35), Joseph Banks wrote in $1770 \mathrm{CE}$ that Maori lived in a 'state of war' (Beaglehole 1962:31), William Anderson in 1777 CE that 'war is their principal profession' (Beaglehole 1967:814), John Nicholas, in 1814 CE (1817 I:29), that Maori were 'barbarians of the most ferocious and implacable disposition', and the missionary Thomas Kendall in 1820 CE that 'war is all their glory' (Wright 1959:119).

These impressions involved a widely accepted assumption that the Maori state of war reflected an unattained level of 'civilisation', a term that entered the English language only in $1767 \mathrm{CE}$ (O'Brien 1993). Banks described Maori as 'uncivilized', and in an 'uncultivated state of nature' (Beaglehole 1962:12), and Johann Forster (1778 CE in Thomas et al. 1996:159; also Darwin 1909:424) admired Tahitians, but saw Maori as barbarians of a 'ferocious and uncultured disposition', if with some redeeming qualities of warrior courage and independence. It followed that their warfare was correspondingly fierce, merciless and unremitting. Anderson (Beaglehole 1967:814) asserted that Maori 'public contentions are frequent and rather perpetual', fought with no quarter given or prisoners taken, and conclude with cannibalism. If not quite a Hobbesian vision of savage pandemonium it did fit contemporary British expectations that clan societies emerging from barbarism into civilisation, not least those in Scotland and Ireland, were torn by constant rivalry and frequent war, such as in John Millar's $1771 \mathrm{CE}$ conjectural history (Smith 2009).

Direct observations of Maori fighting, however, were exceedingly few (e.g. Banks 1769 in Beaglehole 1962:427), compared to inferences drawn from seeing war canoes (waka taua), companies of armed men, captives and sometimes dead bodies or baskets of human flesh. 
The impressions conveyed by those were inflamed at times by calculated Maori scaremongering (Thompson 1997:115), particularly on the matter of cannibalism (Anderson et al. 2014:148-150). The fullest historical evidence of warfare is from the Bay of Islands, where European observations of large war parties departing and returning were combined with eyewitness accounts by their Maori chieftains of what transpired on those expeditions (e.g. Marsden 1820-1824 in Elder 1932:265-267, 355-359, 389-390). The records describe at least one major foray a year from 1807 to 1818 CE, rising to two or three per year up to 1828 CE (Crosby 1999:29-31). This is a high frequency of warfare; in fact, level 4 on the five-point scale used by Ember et al. (2013:53).

These conflicts, however, were part of the so-called 'musket wars', implying the proposition that early access to firearms, axes, potatoes and other goods of European origin by the Bay of Islands people led to more frequent expeditionary wars against tribes that had few or no such commodities. Attacked tribes then hastened to acquire firearms and turn on less fortunate groups again, so that a front of asymmetric military and economic advantage rolled across New Zealand. Irrespective of debate about this hypothesis (Anderson et al. 2014:175-177; Ballara 1998:234239; Crosby 1999:13; Fitzpatrick 2007; Wright 2011), it is undeniable that involvement of a European presence muddies the waters for using historical data from the contact period to represent the frequency and scale of Maori war during the 600 preceding years of exclusive Maori habitation (c.f. Ferguson and Whitehead 1992; Gat 2015), the period of particular interest here.

The prehistory of Maori warfare, insofar as it can be discerned, might shed some light upon how the historical conflicts developed, but it is at least as important for thinking about the role of warfare in the larger-scale development of Maori society. Was the apparently endemic and destructive warfare perceived by early Europeans a longstanding condition in Maori society? Had warfare been a continuously prominent feature of Maori society from the beginning? What does the long-term shape of Maori war suggest about the relevance of potential causes or influences, some operating at centennial scales or larger? These issues are discussed here, initially by considering some existing models of Maori war, then by reference to archaeological evidence and lastly through a new approach to the long-term frequency of Maori war using traditional histories. Warfare is taken as armed combat between territorially defined groups that were formed to defend against violence or project it (paraphrasing Ember et al. 2013:39 and Roscoe 2016:15) and who could act as non-kin toward enemies even if those were closely related. For example, warfare occurred repeatedly in the Kai Huanga (i.e. the 'eat relatives') feud among Ngai Tahu, 1824-1830 CE (Tau and Anderson 2008:162-171), despite close kinship relations among the combatants.

\section{Current hypotheses about the causes and frequency of Maori war}

Explanatory hypotheses of Maori warfare refer variously to intrinsic biological predispositions, societally embedded motivations or extrinsic demographic and ecological imperatives; the three general themes, in fact, of most explanations of warfare among small-scale societies (e.g. Ferguson 2008; Wilson and VanDerwarker 2016).

\section{Biological predisposition}

The most venerable and universal of all models of war is encapsulated in the truism that men are violent by nature. This has been discussed widely in terms of 'coalitional aggression', manifested by ingroup-outgroup construction of the social landscape and expressed as 'male warrior' psychology (Fry and Söderberg 2013; McDonald et al. 2012), with its benefits for individual evolutionary fitness (Glowacki and Wrangham 2015; Lehmann and Feldman 2008). Related hypotheses 
have referred to physiological mechanisms involved in aggressive responses to perceived threat (Berns and Atran 2012), and one of these proposed a 'warrior gene' as particularly influential in Maori violence.

Gene MAOA (the monoamine oxidase enzyme) controls the breakdown of human moodregulating neurotransmitters such as adrenaline, dopamine, norepinephrine and serotonin. Through different histories of genetic selection, alleles of MAOA have evolved with varying levels of activity, and therefore of breakdown rates. MAOA-L, the allele often identified as the warrior gene, has low activity and in populations where it is relatively common it leaves high levels of neurotransmitters that are associated with elevated expressions of bold, impulsive or aggressive male behaviour.

A study of 46 Maori men found that the warrior gene occurred in 70 per cent of cases compared to 40 per cent of a non-Maori sample (Hall et al. 2006; Lea and Chambers 2007). This finding was interpreted as reflecting 'ancient episodes of positive selection and genetic bottlenecks ... due to both environmental pressures during the migrations and behavioural characteristics of Polynesian voyagers', the latter epitomised by a 'warrior tradition' (Lea and Chambers 2007:3). Application of the warrior gene hypothesis to relatively high levels of violence in the contemporary Maori male population provoked criticism on methodological grounds (Crampton and Parkin 2007; Merriman and Cameron 2007) and for fear of social and political repercussions (Hook 2009; Perbal 2013).

Nevertheless, the basic idea is plausible as a contributory factor to conflict. Research in controlled experimental conditions outside Polynesia has shown 'a clear demonstration of the relationship between MAOA-L and actual behavioral aggression' (McDermott et al. 2009:2121). In similar research (Eisenberger et al. 2007 in McDermott et al. 2009:2121), the finding that 'MAOA-L individuals showed greater activity in the dorsal anterior cingulate cortex (dACC), an area that has been associated with distress related to rejection or status challenges' suggests a potentially relevant connection to historical Maori behaviour concerning protection of mana (ritual and social standing derived mainly from ancestry) that frequently led to war.

\section{Societally embedded compulsion}

Early European observers understood the sociopolitical context of Maori warfare. James Cook (1774 CE, in Beaglehole 1961:578) wrote that the population in Queen Charlotte Sound was 'under no regular form of government, or so united as to form one body politick', and that its chiefs had 'no right or power to command obedience'. Anderson (1777 CE, in Beaglehole 1967:813) added that 'no people can be more susceptible of an injury done them, and none more ready to resent it'. Later, Nicholas (1817:306) put the two points together in writing of the Bay of Islands being:

divided as a nation by the form of their government, they [Maori] are split into rival associations, who are taught from their infancy to cherish a spirit of ferocious hostility against each other; and implacable vengeance becomes a necessary duty, to which they are reconciled by habit, while they indulge it without remorse.

That the 'necessary duty' of war arose from fastidious regard for mana among politically fragmented communities remains the dominant explanatory narrative today in historical and anthropological scholarship.

Among Maori, acts of crime or violence, including spoken or observed slights to mana and breaches of tapu (ritual proscription) were regarded as compromising the spiritual relationship between an offended descent group and its ancestors and gods. Rebalancing or repair of that relationship required some form of reciprocal action; against the original perpetrators preferably, 
against their kin or, in the event that neither were possible, against available non-kin. Such reciprocity $(u t u)$ 'was a fundamental principle of all Maori interaction ... a necessity, not an option, for Maori political and social groups which had been attacked' (Ballara 2003:26). There were means of obtaining it short of war, such as recompense in stored foods or valuables, chiefly marriages, or stripping raids (taua muru, hostile plundering expedition) in which offenders allowed themselves to be dispossessed of goods and slaves. These occurred more often among closely related descent groups or within political alliances underwritten by the mana of powerful chiefs.

However, while Maori recognised kinship links between clans at a notionally tribal (iwi) level, and the largely sentimental appeal of common origins in one or another of the ancient colonising canoes (waka), effective responsibility in $u t u$, as in other matters, rested principally at the level of the clan or hapu. Lacking any higher authority capable of mediation, clans had usually to reach, independently or with allies, for 'the ultimate sanction in the Maori system [which] was force applied in warfare' (Ballara 2003:73). It was delivered by the war party (taua toto, hostile expedition for blood) and such actions were thought on all sides to be no less than tika-correct, proper and just. The argument advanced by Maori, then, was that 'wars were fought to restore the mana of groups and their allies damaged by an injury of some kind' (Ballara 2003:26). This sociopolitical model provides a robust explanation of historical Maori warfare at the familial or clan level, suggesting that it was at least a continual activity, but it offers little insight into patterns of war at larger scales of analysis.

\section{Demographic and ecological imperatives}

While 'even economic sources of dispute or competition were subordinated to the political and spiritual consequences of clashes over tapu, mana and utu' (Ballara 2003:163), some warfare was motivated nonetheless by disputes about territory. These were difficult to resolve because Maori property inheritance was tied to ambilineal reckoning of descent-that is, through both male and female lines, potentially legitimating claims from both within and outside the local group and creating a continually fertile source of dispute (Anderson et al. 2014:100-107). Arguments turned upon demonstration of genealogical precedence, but their resolution, including by warfare, often meant that some people had to move away. Andrew Vayda has argued that such warfare-induced dispersal was fulfilling underlying demographic and ecological imperatives. Fundamentally, those derived from resource scarcity and revolved around the proposition that war is almost always incited by food shortages' (Keeley 2016:295).

Vayda (1970:568) deplored 'the general failure of ethnographers to note the systemic relations between the fighting undertaken for revenge and the fighting undertaken for territory'. As he saw it (Vayda 1974:188), 'fighting for revenge ... became fighting for territory whenever some attacked groups failed to defend themselves stoutly or to retaliate adequately'. In such actions, Maori were:

without their necessarily knowing it [performing] essential operations of a system whereby the overall population of New Zealand could grow and be dispersed and whereby access to the resources sustaining this process could be regulated. (Vayda 1970:570)

Clearance of primary rainforest using stone axes was so arduous that it was more economical for a group experiencing population pressure on its established gardens to capture cut-over or cleared land elsewhere than to fell more forest within its own territory (Vayda 1960:113). This strategy created 'a chain-reaction process of aggressive territorial expansion' in which stronger groups expanded at the expense of weaker neighbours and it operated more or less continuously and adaptively to maintain the dispersal of the growing Maori population (Vayda 1970:563). 
The difficulty of clearing primary forest is overstated in Vayda's model. Clearance was achieved principally by fire rather than felling and, instead of replanting the clearings of former owners, Maori preferred to clear virgin forest to expose the most fertile soils (Ballara 2003:18). Most importantly, the notion of incremental territorial expansion through warfare is not supported by Maori traditional history or historical observation. Conflicts occurred between neighbouring families and clans, but organised warfare was conducted primarily against groups at some distance away, usually non-kin.

These ethnographic perspectives on Maori warfare draw attention to mechanisms that imply it was a habitual, random or unpatterned activity, because its propensity was inherent (warrior gene), socially contingent (protection of mana) or ecologically constituted by land clearance (resource competition). Whether they are relevant to understanding the long-term history of pre-European Maori warfare, and of influences or causes operating beyond the local level that might have been involved in shaping its trajectory, is a matter that can be approached first through archaeological evidence.

\section{Archaeological considerations}

Archaeological remains support the elucidation of long-term trends in prehistoric warfare in Europe and elsewhere (e.g. Armit 2011; Carman and Harding 1999), but material evidence of pre-European Maori fighting is scarce. Most of the numerous patu (hand clubs with sharp edges that were used as thrusting and slashing weapons) in museum collections are from ethnographic collecting, especially those (mere) made of jade, which were also marks of rank. Other weapons, including various types of long blades, lances and darts were made of hardwood. Maori did not use bow and arrow or stone-tipped projectiles of any kind. In Maori rock art there are no unequivocal depictions of fighting and very few in which the numerous human figures are shown with weapons. On the rare occasions in which weapons of stone or bone have been documented archaeologically, they have come from sites dated after about 1500 CE (e.g. Skinner 1974:155). Archaeological remains of burnt houses and other structures are quite common, but settlements burned accidentally or were torched upon the death of high-ranking people.

Evidence of mortal wounds occurs infrequently on Maori skeletal remains, and no mass graves of victims of violence are recorded (Houghton 1980). Taking of trophy heads, and heads for sale to Europeans, is well-known historically but specific skeletal marks of decapitation are not recorded archaeologically, and nor is unequivocal skeletal evidence of cannibalism. This might reflect only a scarcity of detailed forensic examination using large samples of Maori skeletal remains; a consequence largely of customary Maori disapproval of human bones being subjected to analysis.

Archaeological evidence of the long-term frequency of Maori warfare, therefore, is almost entirely confined to analysis of $p a$. Of 7022 recorded $p a, 98$ per cent are in the North Island, all but a few within the boundary of kumara (sweet potato) cultivation (Figure 2.1), but the ensuing assumption that population growth associated with agricultural development accounts for $p a$ construction is problematic at first sight. A Maori population of about 100000 at $1800 \mathrm{CE}$ (Anderson 2017 contra Chapple 2017) would have a population density of only $0.3-1.1$ people per $\mathrm{km}^{2}$ within the horticultural boundary, compared to about 15 per $1 \mathrm{~km}^{2}$ for the rest of East Polynesia as a whole, where relatively few forts were built (Anderson 2013). Seasonality of production might have been a crucial difference. Most tropical root crops would produce twice a year or more often and there was, in addition, a wide range of additional food plants, many cropping all year round. Periodic warfare could result in some crop or store losses, but far from all. In temperate New Zealand, however, only one crop of kumara (and a few other tubers) was produced each year at a predictable time. Protection of that single harvest for food and seed tubers, and also rich patches of wild plant foods, was consequently more critical, perhaps inducing pa construction at lower population densities than elsewhere (Anderson 2013). 


\section{Pa Site Count}

- 1

- 2-6

- 6-11

- 11-21

21-50

- 50-132

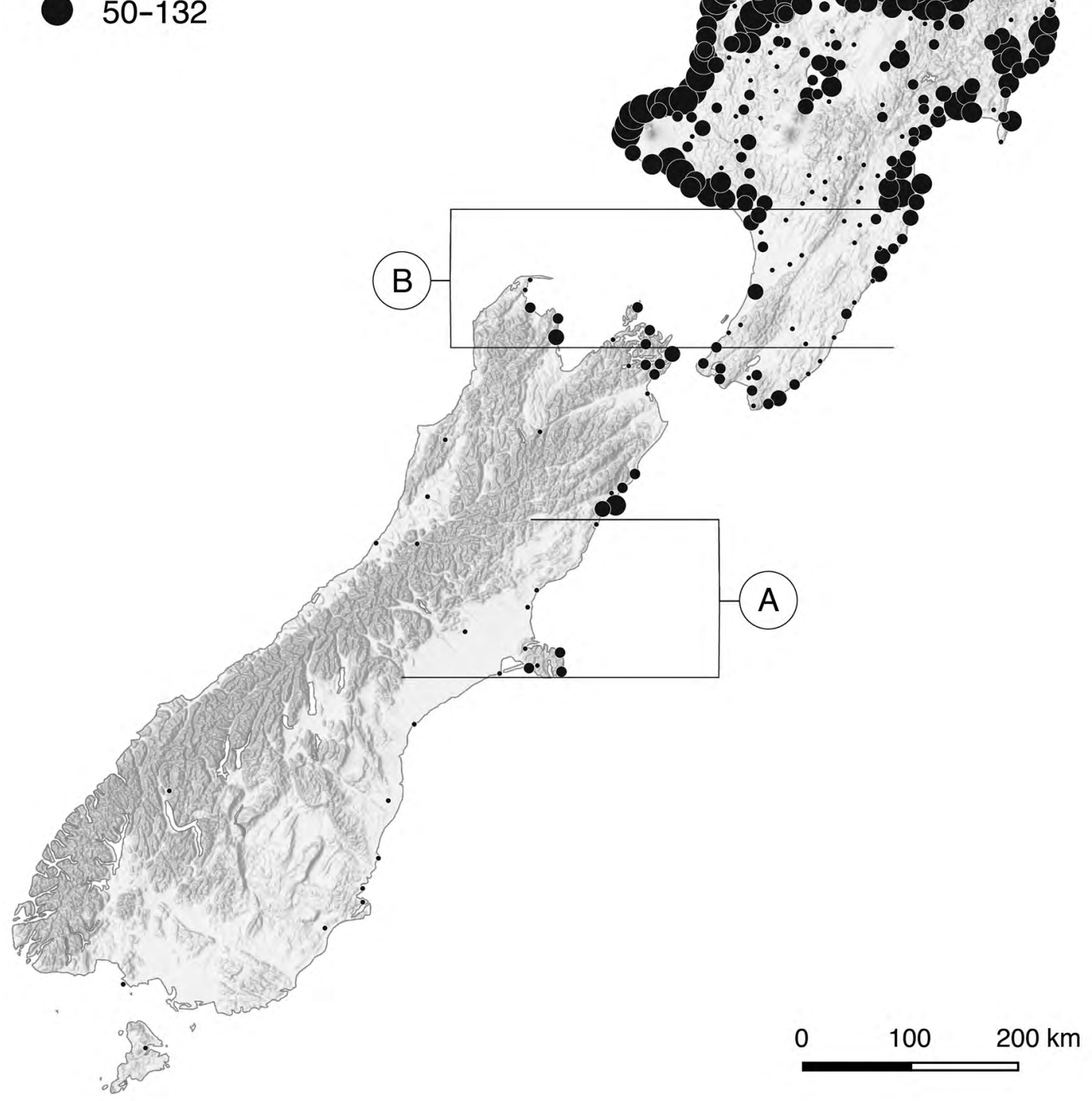

Figure 2.1. Distribution of pa sites and approximate latitudinal spans of marginal cultivation at the fourteenth century (A) and sixteenth century (B).

Source: Atholl Anderson. 
This hypothesis gains theoretical support from research on 'the trade-off between the defensive value of military strength and the commuting costs of the food quest' (Roscoe 2016:35). At very low and very high population densities, dispersed settlement patterns are favoured for smallscale societies, but at medium densities (c. $10-40$ people per $1 \mathrm{~km}^{2}$ in contact-era New Guinea), nucleated defensive settlement is preferred (Roscoe 2016:32-35). As the population density per $\mathrm{km}^{2}$ of arable land in the northern North Island was 11 people, compared to 99-120 people per $1 \mathrm{~km}^{2}$ in tropical East Polynesia, the difference might have been that the Maori population density suited nucleated defence, while elsewhere in East Polynesia the threshold for nucleation was generally exceeded. This density-dependent model could be valid for most $p a$ construction, but not all. Some $p a$ were built well beyond the agricultural boundary, in areas of low population density, as far south as Foveaux Strait.

Other potential explanations for $p a$ building include materialisation of group power by construction size and complexity, and defence of key localities for mobility and exchange. Both can be manifestations of 'costly signalling' (e.g. O'Driscoll 2017) that refer implicitly to military power. In addition, construction for symbolic, ideological or religious purposes cannot be ruled out. Monumental construction was associated with the late prehistoric cult of Oro (a war deity) in Tahiti, and with Lono (an agricultural deity) in Hawai' $\mathrm{i}$, and it is not impossible that $p a$ construction reflects, if only partly, a late prehistoric change of Maori religious orientation, perhaps associated with Rongo (the agricultural deity).

$\mathrm{Pa}$ building began about $1500 \mathrm{CE}$ and as nearly all radiocarbon dates from them have medians after $1600 \mathrm{CE}$, and most of those after $1700 \mathrm{CE}$, an increasing rate of pa construction is implied (Irwin 2013; Schmidt 1996). However, as less than 2 per cent of $p a$ have been radiocarbon dated these trends might not prove representative. All types of $p a$ were built contemporaneously. There is accumulating evidence that groups of $p a$ were set out in landscapes to provide extensive interlinking defence arrangements. On north Kaipara head, 20 pa sites were built at the same time in the eighteenth century and are set in a strategic pattern, indicating either a large group migration, or a concerted response to external threat by a large resident group (Irwin 1985). On Ponui Island the distribution of $p a$ built in the early sixteenth century indicates a similarly short span of $p a$ building and a strategic defensive system for the island as a whole (Irwin 2013). $\mathrm{Pa}$ landscapes in Taranaki produced comparable evidence (Prickett 1982, 1983).

Tightening of territoriality after about $1500 \mathrm{CE}$, implicit in $p a$ construction, is also documented by attenuation of early long-distance exchange networks involving obsidian and stone adzes (e.g. Turner 2004). A similar conclusion can be inferred for ritual behaviour. The small, pavedstone ritual features that existed in East Polynesia at the time of migration to New Zealand are recorded from a number of early Maori sites. It can be argued that while they, and also cemeteries, were safe from hostile destruction in early open settlements, the tensions arising from growing population density on and around horticultural lands created a need for later groups to protect their ritual assets. Burials were hidden away in caves and forest, and ancestor carvings, godsticks, bundled bones and other sacred things were taken into $p a$, which became sanctuaries for clan spirits as much as safe storage and protection for people (Anderson 2014).

These data and interpretations suggest that most $p a$ were intended primarily for defence of agricultural groups and their tangible and intangible assets. It is worth noting that the only other population of Polynesians in the New Zealand region that survived into historical times, the Moriori of the Chatham Islands, had no agriculture, had proscribed warfare and built no pa. It was only with Maori invasion of the Chathams in the 1820s CE that some $p a$ were built (Anderson 2014). Maori construction of $p a$ in mainland New Zealand after $1500 \mathrm{CE}$, then, can 
be seen as a response to warfare, or its threat, resulting from competitive pressure on cultivable land and other resources. Whether long-term change in the relative frequency of warfare actually followed this pattern is a matter than can be addressed independently through oral traditions.

\section{Long-term frequency of Maori migratory war in oral traditions}

Maori oral traditions were organised iteratively, by generations, and the narratives associated with ancestors often followed a convention of receding causation in which each event was seen as the consequence of a previous event of the same kind, and that of an earlier event, and so on in multigenerational chains. There was no reflexive commentary or recognition of trans-tribal patterns of war. If larger processes were at work on the shape of war, they were not recognised or understood, or they were simply extraneous to the purpose and practicality of keeping an oral account of clan ancestry and fortunes. As warfare and other conflicts had to be committed to memory in these oral traditions, many episodes of localised conflict have probably been discarded over the years, and it might be expected that proportionately fewer of the older events were retained. With no way of knowing such patterns of discard, or of variation in the extent of discard between group traditions, any comparative analysis based only on references to conflict would be rendered nugatory.

It is better to choose another kind of activity that was more certain to be remembered and that was associated closely with elevated levels of warfare. Group migrations in which clans, or sections of clans, moved into new localities were almost inevitably hostile incursions involving warfare that induced migration and subsequent warfare, among other actions, that produced residential rights for newly arrived migrants. Furthermore, as oral traditions were the foundation of property ownership, sustaining rights in new territories required remembering the genealogies and narratives that supported each case. Migrations, then, can be taken as an index of the frequency of notable warfare; of events which had high status and lasting significance for the groups concerned (c.f. Thorpe 2003:146).

The Maori evidence is particularly useful in elucidating the frequency of migration warfare, and spatio-temporal patterns in it, because the evidence came from hundreds of independent groups. As clans were highly dispersed at low population densities in the comparatively huge landmass of New Zealand, and effective Maori political authority peaked at the clan level, the numerous individual traditions were never reduced to the relatively few aristocratic or monarchical lines that came to dominate traditional histories in state-level Tonga, Hawai' $i$ and Tahiti.

The singular abundance and detail of Maori traditions invited some early scepticism about their historical validity, but Edward Shortland, among others in the early nineteenth century who were fluent in Maori and worked with Maori on the practical problems of land tenure to which the traditions were recognised on all sides as crucial evidence, showed that there was remarkable consistency among numerous and widely separated clan records. He concluded that the traditions were historical in the common sense of that term and observed that they distinguished carefully between mythological, fabulous and historical narratives recognising, for example, a distinction between supernatural and historical locations of Hawaiki, the Maori homeland (Anderson et al. 2014:40-49). A recent test of the historicity of genealogies examined 156 migration canoe genealogies for their estimates of the age of initial colonisation and found that initial migrants arrived 1280-1370 CE (Anderson et al. 2014:60-64). The overlap of ancestral names between Tahitian, Cook Islands and Maori genealogies immediately before the period of migration supports this interpretation, and it is also congruent with radiocarbon dated 
events in archaeology and palaeoecology that are markers of initial human colonisation in New Zealand (Anderson et al. 2014:32-34). With that assurance of the general historicity of Maori traditions, a method of estimating the ages of migrations recorded in them was devised.

\section{Working method}

The relative incidence of migratory warfare was estimated in the following way (further detail in Anderson et al. 2014:60-64, 104-105, 111-117). For each group, generally a clan but sometimes known only under a later tribal name, genealogies were collated that showed continuously successive generations between named ancestors who arrived in initial colonising canoes and historical figures who lived in the early nineteenth century. For some groups, marriages and other interactions across groups were needed to reconstruct full genealogies. A generation interval of 30 years was adopted, after Fenner (2005) who used large historical datasets to calculate generation length (combining the mean age at parturition for females and the mean age at paternity for males) for small-scale societies, obtaining figures of 28-30 years. For combined agricultural-foraging societies his data suggest about 29.5 years, here rounded to 30 , which is significantly longer than the 20 or 25 years commonly used hitherto in analysis of Polynesian genealogies. Historical evidence that described the period of flourishing of an early-nineteenthcentury ancestor was used to set the dates for the latest generation, and then successive 30-year intervals were allocated to each preceding ancestor. The approximate accuracy of this procedure was checked by comparing the positions occupied in different genealogies by ancestors who interacted with each other in traditions from different sources. The chronological intervals for ancestors who were involved in specific migrations and associated warfare recorded in the traditions were noted, and these periods were plotted for the different clan or group lineages to determine whether there were cross-lineage correlations of the same phases of migration and war.

This method was applied to genealogies and traditions of groups originally in the eastern North Island who ended up in the South Island. I looked also at the migration and warfare of the Tainui canoe people who colonised the Waikato region, to see whether there was similar temporal patterning in the incidence of migratory warfare (Anderson 2013). The genealogies and traditions were taken primarily from Tau and Anderson (2008) for the eastern migrations; Jones and Biggs (1995) for those in the Waikato District; and Crosby (1999) for historical migrations into the southern North Island and northern South Island.

\section{Migration and warfare}

Relatively high migration frequency can be observed as three phases (Figure 2.2).

\section{Phase I: Colonising migration}

In the first phase, New Zealand became inhabited, for the first time, by migrants arriving in 12-20 canoes from 'Hawaiki', meaning in this case the Cook, Society or Austral Islands. Maori traditions say that 'in the time of Houmai-tawhiti there had been a great war, and thence there were many battles fought in Hawaiki'. In one of these, 'Uenuku and Toi-te-huatahi went to make war on Tama-te-kapua and his people, and some fell on both sides' after which Uenuku's people were defeated by Houmai-tawhiti (Grey 1954 (1855):99-104). Uenuku's son, Kahuiterangi (later known as Paikea, 'the whale rider') migrated to New Zealand and was the progenitor of Ngati Porou, Ngai Tahu and other tribes originating in the eastern North Island. Tamatekapua brought the Arawa canoe to New Zealand and its crew populated much of the Bay of Plenty. The Tainui canoe under Hoturoa arrived at the same time and its people occupied the Waikato region. More canoes arrived in the same period, about 1280-1340 CE and took possession of other districts, mostly in the North Island. Some conflicts are recorded, but almost no warfare. 


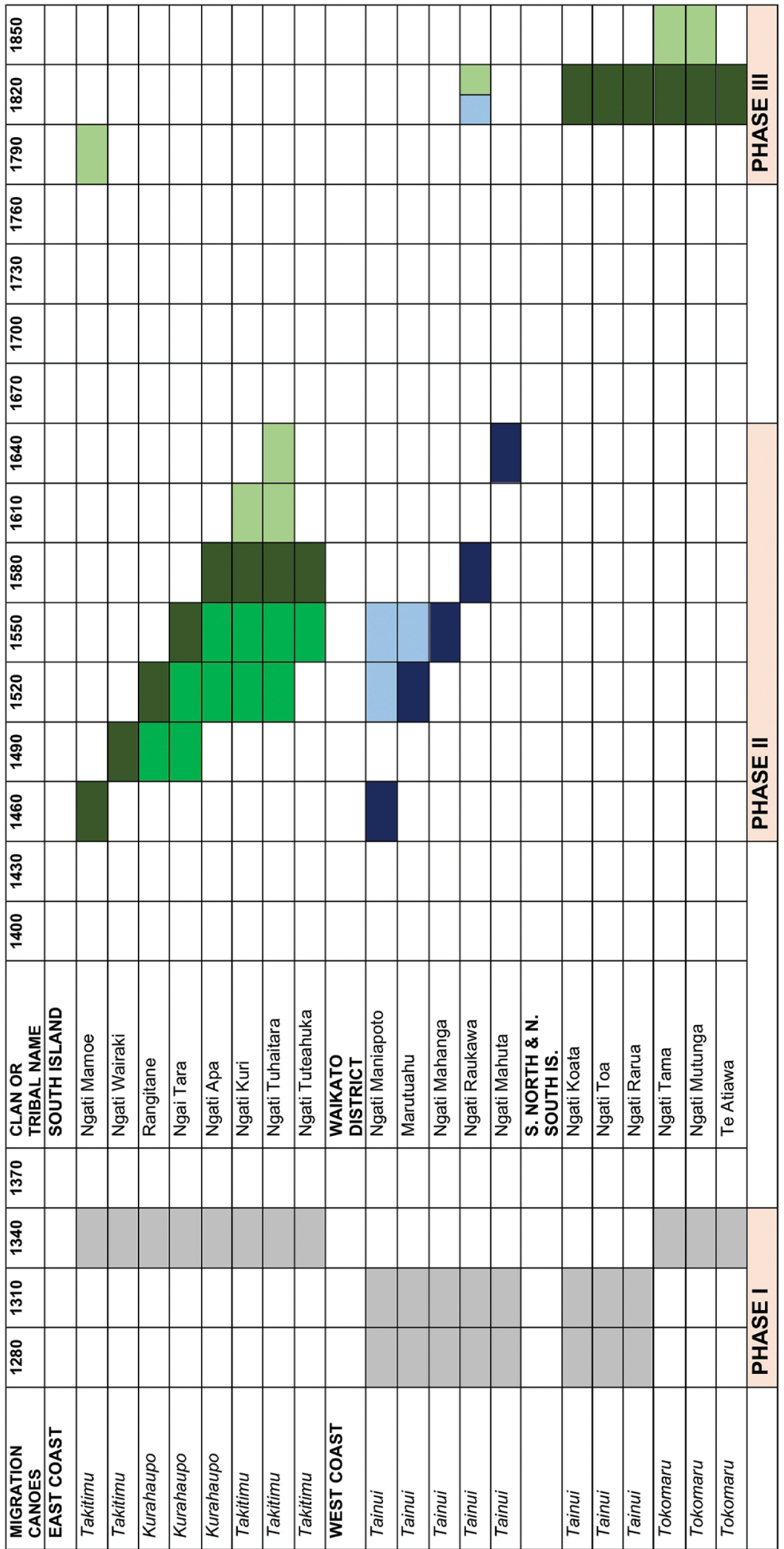

Figure 2.2. Temporal distribution of traditional Maori migrations by groups originating on the east and west coasts of the North Island, and their canoe ancestors from East Polynesia.

Key: grey = colonisation canoe landings; dark green = migration into the South Island; mid-green = preceding migrations in North Island; light green = subsequent migrations in South Island or to Chatham and Auckland islands; dark blue = migrations into interior of Waikato and Auckland districts; light blue = subsequent migrations in North Island. Migration phases shown in pink.

Source: Atholl Anderson. 


\section{Phase II: Early tribal migration}

The second phase refers to migration within New Zealand. The group names that follow combine the terms 'Ngati', 'Ati' or 'Ngai' (clan or tribe), with an identifying ancestral name, such as 'Tahu' or 'Wairaki'. The migrations were primarily from the East Coast of the North Island into the lower North Island and then into the South Island. Ngati Mamoe migration to the South Island began after the death of Tukapua in the fifteenth century (Figure 2.3). Ngati Wairaki migrated from the East Coast, probably with Ngati Tumatakokiri, as both spent some time in the Taupo region and ended up in Whanganui, from where Ngati Wairaki migrated to the western South Island under Tuaroaroterangi about $1500 \mathrm{CE}$.

Ngati Kahungunu and Ngai Tahu migration began with the killing near Gisborne of the greatgrandsons of Kahungunu, which split the community. Rakaihikuroa and his son, Taraia, took their people, and Ngati Ira under Te Aomatarahi (Rakaihikuroa's uncle) to Hawkes Bay about 1500 CE, while Rakaipaka, half-brother of Rakaihikuroa, and the descendants of Tahumutu known as Ngai Tahu moved to Wairoa. Ngati Kahungunu migration to Hawkes Bay compelled remaining Ngati Mamoe to move south into the Wairarapa, while conflict there between incoming Ngati Kahungunu and resident Ngai Tara led many of the latter to move to Wellington about 1500-1530 CE. With Rangitane migrating south-west to Manawatu, some by way of southern Wairarapa, and Ngati Ira coming from Poverty Bay, the influx of migrants threatened to overwhelm Ngai Tara and Rangitane in the Wairarapa. They began migrating to the South Island during the mid-sixteenth century under Te Rerewa and others.

Following another conflict, many Ngai Tahu and Ngati Ira migrated to Wairarapa and Wellington in the mid-sixteenth century. Some of Rakaipaka's children, notably Rakaitekura, Tuhiku and Waitai, moved to Wellington, and soon after to the South Island. Within the same generation, conflict among newly arrived groups of Ngati Kahungunu, Ngati Ira, Ngai Tahu and Ngati Porou in the Wellington district led to a series of migrations into the South Island at the end of the sixteenth century led by Tutekawa, Te Ao Hikuraki, Puraho and Tuteahuka, among others. These were mostly groups of Ngai Tahu allegiance. They fought Ngati Mamoe, and each other, in the South Island as migration continued there until the early seventeenth century (Tau and Anderson 2008:153-161).

Although many different groups were involved in this phase of migration, the shape of their movement followed the same general pattern. That observation prompts the question of whether there were broader imperatives of migration than the particular conflicts involved, and a test of that is to consider Maori migration history elsewhere. I looked at the situation of the Tainui groups for comparison. The Tainui traditions show that until six to eight generations (180-240 years) after the arrival of the Tainui canoe, there was relatively little conflict and almost no migration into the inland Waikato (Jones and Biggs 1995). Archaeological data confirm the relative absence of inland settlement at this time (Anderson 2016). Then, from the late fifteenth century to the mid-sixteenth century, there was territorial expansion east, north-east and south-east from Kawhia (Figure 2.2), with emerging political divisions among the main lineages, derived from Tawhao, Tuhianga and Puhanga. Tawhao divided the Kawhia lands between Whatihua and Turongo, with the latter required to live inland. He settled in the upper Waipa valley and soon after, more coastal groups under Rereahu and Hotunui moved into the Waikato valley, then later to the Firth of Thames, where Marutuahu began a vigorous campaign to establish authority over eastern Hauraki. Maniapoto lived mainly in the Waitomo district; his younger brother Matakore, and also Mahanga, in the Waipa valley (Jones and Biggs 1995). 


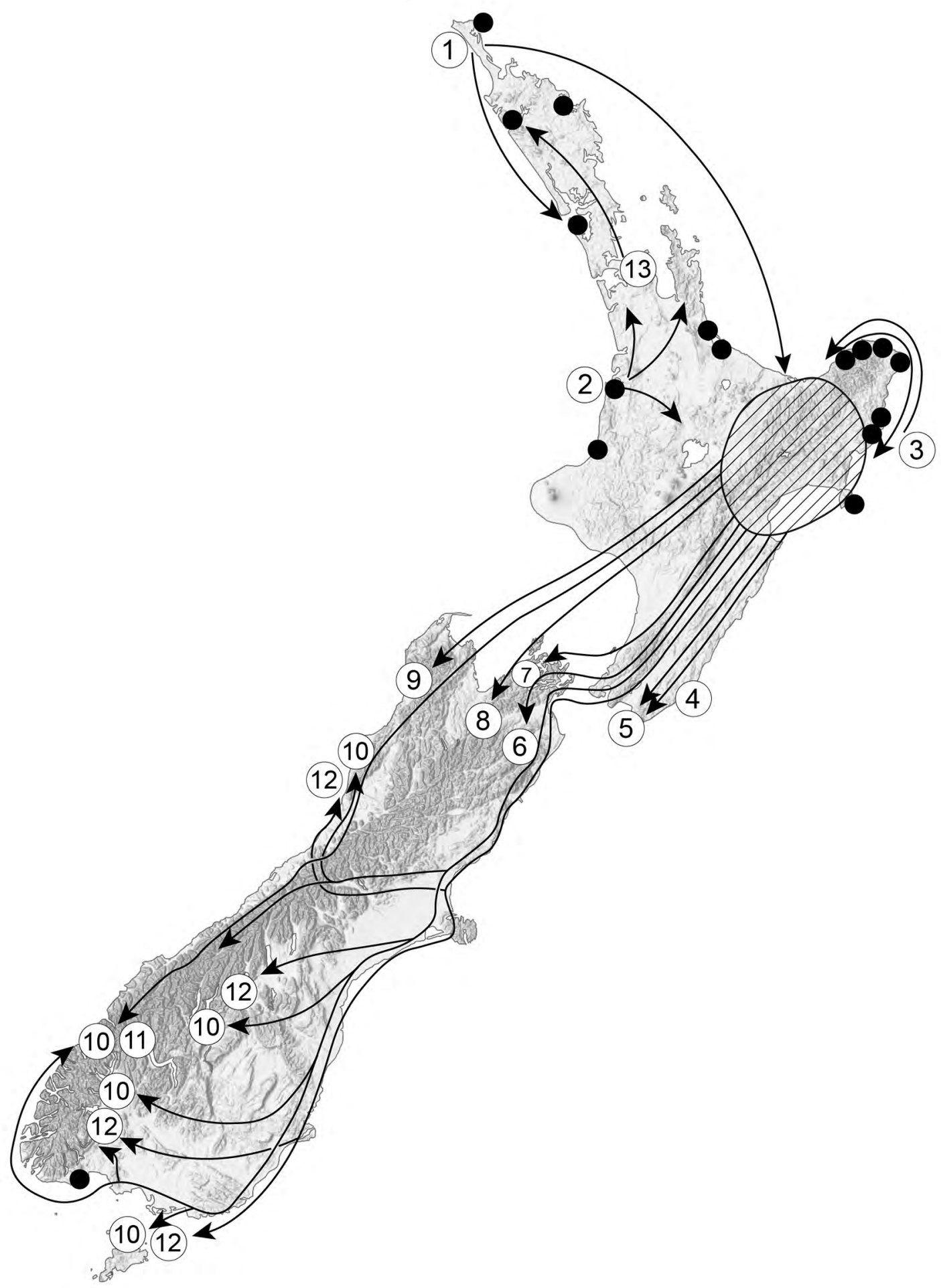

Figure 2.3. Phase I and II migrations.

Black dots = main landing places of colonising canoes (Phase I). Oval area with diagonal lines = approximate area of origin of most Phase II migrations. Arrows show direction of migrations. Groups involved: 1 Ngati Awa; 2 Tainui; 3 Ngai Te Rangi; 4 Ngati Kahungunu; 5 Ngati Ira; 6 Rangitane; 7 Ngai Tara; 8 Ngati Apa; 9 Ngati Tumatakokiri; 10 Ngati Mamoe; 11 Ngati Wairangi; 12 Ngai Tahu; 13 Te Uri o Pou.

Source: Atholl Anderson. 
A brief survey of some other northern traditions suggests that migrations occurred in the sixteenth century in other regions as well. Marutuahu and his sons forced Te Uri o Pou out of Hauraki and they migrated north to Hokianga. In Nga Puhi tradition, the first big migration occurred in the mid-sixteenth century when early Nga Puhi expansion caused the migration of Northland Ngati Awa to the Bay of Plenty and Taranaki. The Ngati Apa migration from the Bay of Plenty occurred at the same time, reaching the south-west coast of the North Island about $1550 \mathrm{CE}$. Long migrations in this phase had ceased by the early seventeenth century.

\section{Phase III: Late tribal migration}

The latest migrations derived also from warfare in the North Island, especially in the northern half. Warfare seems to have increased in the Waikato region in the eighteenth century, with conflict beginning between Ngati Raukawa and other Waikato groups, and then further north between Waikato and Nga Puhi about 1750 CE. In the Waikato, warfare came to a head with the battle of Hingakaka ('the fall of parrots', referring to the great loss of chiefs), probably in 1807 CE. This was the largest battle ever fought in New Zealand, with about 13000 warriors involved. It is important to note that neither this battle, nor many others until about $1815 \mathrm{CE}$, involved muskets, and also that both the locality (inland Waikato) and the reasons for the battle (Jones and Biggs 1995: 348) preclude any suggestion that it was fought over access to European goods and services. It was a traditional affair. On one side were most of the resident Tainui canoe descendants belonging to the Waikato and Ngati Maniapoto people, with allies from Northland Ngati Whatua. The attacking force, 7000-10 000 strong, centred around Ngati Raukawa, a people of Tainui and East Coast descent, and it included the west coast Tainui people of Ngati Toa; Te Ati Awa, Ngati Ruanui, and Whanganui from Taranaki; and groups of Te Arawa, Ngai Tuhoe, Ngati Kahungunu and Ngati Porou from Bay of Plenty-East Coast (Jones and Biggs 1995:348-357). All had accumulated grievances of $u t u$ and mana against Waikato, but Waikato won and that had major repercussions for those Tainui groups who had opposed them.

In 1816-1821 CE, long-distance campaigns in which muskets were used by Nga Puhi, Ngati Whatua (Auckland) and Waikato virtually encircled the North Island. Ngati Toa joined the 1819 CE Ngapuhi campaign, called Amiowhenua ('encircle the land'), but alliance with Ngapuhi, who were generally in opposition to Waikato, on top of opposition at Hingakaka, brought overwhelming retaliation by Waikato and Ngati Maniapoto. Ngati Toa, and their neighbouring tribes Ngati Koata and Ngati Rarua, were forced to migrate south. They were joined successively by the Taranaki tribes Ngati Tama, Ngati Mutunga and Te Atiawa, which became exposed by the evacuation of northern allies. A large section of Ngati Raukawa, defeated again by Waikato and under pressure from Hauraki migrants fleeing Ngapuhi, also migrated south, eventually ending up alongside their Ngati Toa allies on the south-west coast of the North Island (Crosby 1999:90-93, 136-149, 160-161, 182-185, 200-206). In 1827 CE, Te Rauparaha (Ngati Toa) led a campaign against the tribes in the northern South Island, and in 1829-1832 CE against Ngai Tahu to the south. The result of these events was that the southern North Island and northernmost South Island became occupied largely by people from the groups defeated at Hingakaka (Figure 2.4). There were some other, smaller migrations around this time. In the South Island, Ngai Tahu and Ngati Mamoe reached an accommodation, sealed by marriage, about $1790 \mathrm{CE}$, but some Ngati Mamoe, unable to accept this, migrated into the western lakes and fiords (Tau and Anderson 2008:152-158). 


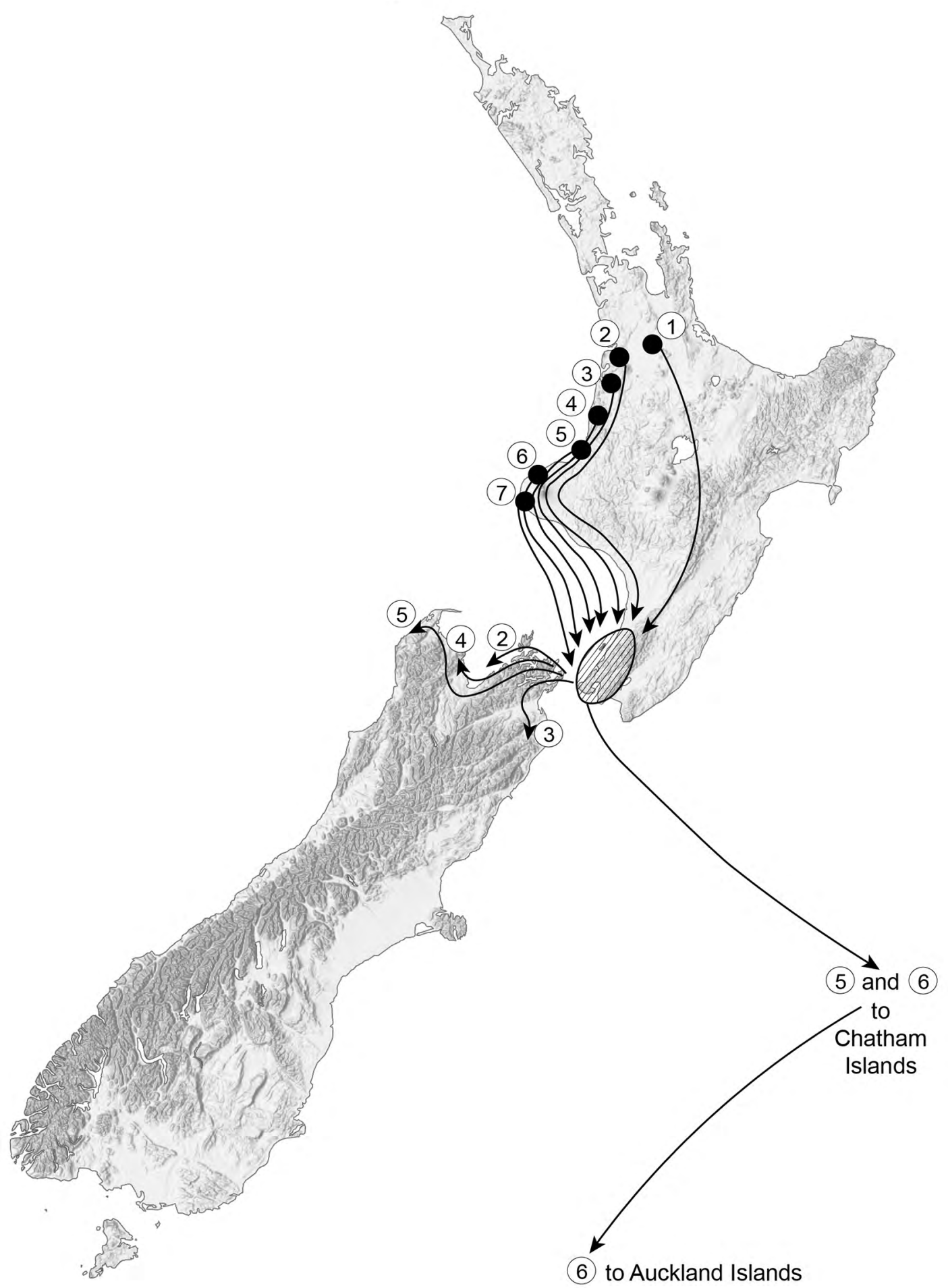

Figure 2.4. Phase III migrations. Oval area with diagonal lines shows approximate area of origin of most Phase III migrations.

Arrows show direction of migration. Groups involved: 1 Ngati Raukawa; 2 Ngati Koata; 3 Ngati Toa; 4 Ngati Rarua; 5 Ngati Tama; 6 Ngati Mutunga; 7 Te Atiawa.

Source: Atholl Anderson. 


\section{Long-term patterns of warfare and migration}

1. In the three cases here, rising warfare eventually triggered migration. From the perspective of the traditions, disputes about resources, the deaths of significant individuals on the East Coast, and rebellion against senior clans in the Waikato-each initiated phases of relatively intensive warfare. As that proceeded, some groups shifted out of the areas of contention. The traditions say, or imply, that they were compelled to move by the fortunes of war.

2. Migration occurred incrementally. In Phase I, the canoes left individually or in small fleets, probably over a period of decades, because some genealogies begin later than others-for example, those for the Takitimu canoe (Anderson et al. 2014:63). Similar serial or staggered migration occurs in Phase II (Figure 2.2), where early Ngai Tahu were effectively forced to move across Cook Strait and then their success in capturing territory from Ngati Mamoe encouraged other related clans to follow suit. In the Waikato, it is not so clear that migration inland was compelled by war so much as a means, initially, of separating competing lineages (Jones and Biggs 1995), but movement by other clans proceeded serially. In Phase III, obligate Ngati Toa migration from Kawhia prompted its allied clans to follow suit in a domino process.

3. Nearly all migrations were from north to south; from the tropical to the temperate zone, from warmer to cooler districts in New Zealand; from higher to lower population densities and from reliable to marginal agriculture, or beyond into foraging. There were attractions to the south, notably jade and comparatively abundant wild food resources in the South Island, and Ngati Toa were interested in the trading opportunities with Europeans that were emerging in Cook Strait, but the overall pattern is nevertheless one expected of involuntary or obligatory migration-that is, exile (Anderson 2006).

The phases of migration are spaced fairly evenly across the pre-European era (Figure 2.2): Phase I about 1280-1340 CE, Phase II about 1460-1640 CE and Phase III beginning around 1820 CE. The phases are separated by intervals of less frequent warfare, lasting a century or more, and the peaks of activity occur about 1300, 1500-1600 and 1820 CE, approximately 200 years apart. This suggests that while warfare might have been endemic at the ethnographic level, at a larger scale it may not have been an inescapable part of social existence (Ferguson 2008:34).

These observations beg numerous questions, including whether the patterns noted here would be sustained in a more comprehensive study of Maori traditions. That remains to be seen, but if the current data are assumed as representative, then the principal issue raised is this: why were there pulses in the incidence of migration and associated warfare?

\section{Discussion}

One of the more striking aspects of the migration war data is that they do not show a general directional trend, such as migration increasing in frequency from early to late across the pre-European era, the inverse, no change in time or simply random activity. Instead, they are patterned as three separate peaks more or less equidistant in time. This raises a question as to whether the activity was in some way cyclical. The notion of regularities, oscillations or cycles in cultural activity, and of the interlinking or coupling of different cycles derived from diverse variables of cultural and natural origin - the historiographical interests of cliodynamics (Turchin 2011) - is so intuitively plausible that it is worth noticing such phenomena even when they are unable to be satisfactorily explained. Human behaviour operates on multiple scales, from the quotidian to the longue durée in historical terms, and even longer on archaeological time scales. The oscillation of multiple trajectories means that, at certain junctures, imperatives from one 
level influence behaviour at another. In that context, the periodicity of migration and warfare needs to be considered in terms of potential endogenous governors and exogenous drivers such as population growth, climate change and political development.

\section{Endogenous periodicity of migration and war}

It has been conjectured that Oceanic migration in general involved repeated cycles, each a binary phase of settlement stability and mobility, in which the overall trajectory of repetition was accelerating and being driven endogenously in some way (Anderson 2001). One way could be that migration propensity, whether genetic or cultural in origin, was heritable. If so, it could become proportionately more frequent with successive migrations of daughter populations through demographic bottlenecks, increasing the frequency of migration over the long term (Anderson 2013). Generally decreasing intervals of migration between Lapita (c. 3100 years ago), marginal West Polynesia (c. 2000 years ago), Central East Polynesia (c. 1100 years ago) and South Polynesia (c. 700 years ago) offers some evidence potentially relevant to this proposition (Anderson 2001), and that migration peaks at approximately 200-year intervals in New Zealand adds more. Speculating further, a propensity to migrate might be linked to genetic traits for boldness that were also expressed as a willingness to make war.

A similar kind of explanation for modulated warfare frequency might be an approximate periodicity in the accumulation of grievances. Some grievances between the crews of migration canoes were brought to New Zealand, for instance an offence that resulted in the burning of the Arawa canoe, but marriages between early canoe communities helped to prevent any serious trouble for some generations. In time, however, the closeness of individual and group descent, and a proportionate ability to meet or know other people in a district population, declined with population growth (Roscoe 1993) so that kin become increasingly non-kin and liable to be regarded as potentially hostile. It can be conjectured that ramifying political divisions thus increased the accumulation of grievances for all groups increasing, in turn, the frequency of war and migration required to resolve them. As the colonising canoes all arrived within a relatively short period, it would not be surprising to find in a comprehensive analysis of Maori traditions that warfare increased at about the same rate everywhere, peaked in about the sixteenth century, declined as grievances were resolved by war and migration, and then increased again to a peak during the late eighteenth and early nineteenth century.

\section{Population growth}

Changes in Maori population growth rates, and in population density, affected resource competition and might have impelled variation in the frequency of migration and war. Opinions vary about the shape of Maori population growth up to the turn of the nineteenth century, but the process was probably logistic - that is, dependent upon availability of resources (Anderson 2016). Computer simulation of Maori population growth, assuming a logistic curve and beginning with 200-400 men and women in the late thirteenth century, indicates that the growth rate declines about the sixteenth century (Whyte et al. 2005). Summed probability distribution of radiocarbon dates, although prone to some methodological problems (Dye 2016), shows that Maori population overall increased up to the sixteenth century and then plateaued until $1800 \mathrm{CE}$ (Brown and Crema 2019). In central New Zealand a small secondary spurt of population growth occurred up to $1650 \mathrm{CE}$, possibly reflecting the southward migrations discussed here, while in southern New Zealand the population peaked around $1400 \mathrm{CE}$ and remained low thereafter (Brown and Crema 2019). Density-dependent decline in the population growth rate, beginning in the sixteenth century, is consistent with an origin of $p a$ construction in the northern North Island, given that this reflected warfare arising from population pressure on agricultural land. 
The interlinkage of population dynamics with war among small-scale societies ('internal' warfare) is well known. Turchin and Korotayev (2006:123) argue that population size and warfare intensity 'should oscillate with long periods (ranging from one to three centuries depending on parameter values) and that these two variables should be phase-shifted with respect to each other', with peaks of warfare following peaks of population growth. In the Maori case, if migration was driven by warfare that increased with population growth, then a model could be sketched as follows. In central East Polynesia, population pressure resulted in warfare that induced migration, beginning in the thirteenth century and at least some migrants went to New Zealand. There, low population at colonisation and for a century or more later, precluded warfare, but growing population density and warfare frequency eventually induced migration southward into regions of lower population density. This suppressed territorial competition in areas of migration origin, and thereby warfare frequency, until a continuing rise in population density led to increasing warfare and migration again in the early nineteenth century.

\section{Climate change}

Climate change is another potential influence upon variation in migratory war. Increased warfare in non-state societies has been shown as a common response to climatically induced change in the distribution or productivity of food resources (Burtsev and Korotayev 2004:32; Ember et al. 2013:35). A conjunction between population decline, climate cooling and subsistence reorganisation has been shown as a periodic phenomenon in Holocene Britain and Ireland (Bevan et al. 2017), and increased warfare at such times was recognised by Zhang et al. (2007) in European and temperate zone Chinese historical records 1000-1900 CE. A similarly reciprocal relationship of enhanced conflict and episodes of environmental shock is described for droughtprone tropical regions by von Uexkull et al. (2016). It is apparent that a crucial factor was not just change in the geographical extent and productivity of resources, but rather the confidence that people could have in their availability - that is, in levels of food uncertainty.

Could something similar have occurred in New Zealand? Initial colonisation occurred during the 'Polynesian Warm Period', which persisted, with fluctuations, up to about $1400 \mathrm{CE}$. There was then a fairly sudden, substantial, decline into the Little Ice Age (LIA), coldest and wettest at 1500-1670 CE, which gradually ameliorated up to about $1850 \mathrm{CE}$. Across the LIA as a whole, mean summer temperature dropped by $0.6^{\circ} \mathrm{C}$, and in winter by about $1{ }^{\circ} \mathrm{C}$, in New Zealand, but the drop was especially sharp and deep during the beginning of the LIA, where some data show a $1.5^{\circ} \mathrm{C}$ fall (Anderson 2016). Such changes are comparable in scale to those that had profound effects on European rural economy and society.

Kumara will not grow in soil temperatures of less than $15^{\circ} \mathrm{C}$, which put the southern limit of cultivation during the colonisation era at about $43^{\circ}$ south (North Canterbury). A fall in mean annual temperature of $1.0-1.5^{\circ} \mathrm{C}$ at sea level by the sixteenth century is equivalent to moving the cultivation limit $145 \mathrm{~km}$ further north, and a fall of $1.5^{\circ} \mathrm{C}$ in mean summer temperature is the equivalent of shifting it $220 \mathrm{~km}$ north, to $41^{\circ}$ south, the southern North Island. In that case, agriculture had probably become marginal almost as far north as Hawkes Bay (Anderson 2016), which might account in some degree for the origin of sixteenth-century warfare and migration on the East Coast. Heavy rainfall was also problematic for kumara, especially in the autumn and early winter before the crop was lifted, and also through dampness when the crop was stored in covered pits. Rainfall increased substantially over most of New Zealand in the coldest years of the LIA, 1400-1560 CE, and it is quite possible that it led to frequent rotting of kumara in the ground, creating a crisis of the same kind, if not on the same scale, as the Irish potato famine. 


\section{Political reorganisation}

Whether political reorganisation was also involved in the patterning of war is open to question. By the eighteenth century, at least, exclusive clan control of territoriality seems to have weakened in the northern North Island as some groups achieved a level of political consolidation that foreshadowed the rise of modern tribes. This process has been seen, variously, as the beginnings of a change toward a class society, the developing primacy of political over kinship relationships and a move toward settlement or community-ordered societies (Anderson et al. 2014:125-126 and references therein). How far back it goes is hard to tell but if, for example, the sixteenth-century ousting of Ngati Awa from Northland is seen as an early move in the rise of Nga Puhi, then it might have begun to emerge at the time of the Phase II migrations.

Any greater political complexity can be ruled out by an absence of demographic prerequisites. State-like reorganisation occurred in Hawai' $i$ but the historical population there was four times larger than in New Zealand and its gross population density was 65 times greater (Anderson 2016). Nevertheless, in Northland, the district of highest population density, early nineteenthcentury accumulation of fine goods and services extracted by Nga Puhi from client groups in Thames and Bay of Plenty, the construction of large formal houses (whare whakairo) and hakari (feasting) display stages, and the carrying of high chiefs in chairs of state suggest that political innovation was heading in a similar direction. The Waikato groups were favouring lines of descent that continued into the later nineteenth-century Maori King movement, and among highly dispersed Ngai Tahu, issues of political integration as a tribe under a paramount chief were apparent by the late eighteenth century. It is possible that these political changes influenced the rise of warfare frequency before and during the Phase III migrations.

Slavery could also have played a part. The introduction of potatoes and other European crops facilitated Maori agrarian commerce which, in turn, underwrote the logistics of the large, musket-armed raids of the early nineteenth century, and was reinforced by the capture of slaves (Fitzpatrick 2007). There is no traditional evidence about the pre-European development of slavery and it is known only by its historical occurrence (Petrie 2015). However, a combination of extensive, unused, allophanic soils suited to agricultural expansion in the northern North Island, and a medium-density population level in that region by the sixteenth century or so, were conditions in which slavery is predicted to emerge (Lagerlöf 2009). It may be no coincidence, then, that most of the Phase II and Phase III migrations began around the margins of the main horticultural territories; that is, from districts of relative disadvantage, including in military strength, where slaves would probably have been sought by the more powerful and populous groups who were developing extensive agricultural estates (Anderson 2016).

\section{Conclusions}

Existing models of Maori conflict are essentially ethnographic in conception and offer little insight into the patterning of warfare and what might have shaped it, at centennial or greater scales of consideration. In addition, the significance to warfare of $p a$, practically the only source of archaeological data, is to some extent enigmatic. Fortunately, there is an alternative archive of pertinent data contained in numerous, independent, genealogically dated, oral traditions of clan and tribal history extending across the pre-European era. In order to extract a sense of the frequency and intensity of warfare from these data, it has been assumed that there is a covariance between elevated warfare and phases of migration, as suggested by traditional evidence that migration was generally involuntary and accompanied throughout by warfare. The main result of a pilot study of East Coast and Waikato traditions is that migration and associated war appear 
to have fluctuated at a centennial scale and were possibly cyclic, with phase peaks at about 200year intervals. More comprehensive research is needed to determine whether this result is valid for Maori as a whole.

Turning to the original questions, warfare was frequent when Europeans arrived and it continued during the early nineteenth century, for entirely valid traditional reasons. It became more frequent and intensified by differential access to European commodities, including muskets and potatoes and, to that extent, early European impressions of Maori warfare cannot be taken as representative of its long-term state. The frequency and assumed intensity of warfare, as measured by the frequency of associated long-distance migration, was not constant through Maori history, nor did it follow a simple trajectory of incidence. Warfare was infrequent, at least, for up to two centuries after colonisation, and it may have declined also between migration phases II and III. Warfare was more frequent immediately prior to the thirteenth-century colonising migrations, again in the sixteenth century and then in the early nineteenth century.

Several potential explanations of periodic oscillations in Maori migration and warfare have been discussed. The current state of evidence and understanding of these does not encourage a preference for any one, or combination, of them as explaining the long-term patterning in Maori war. Nevertheless, setting them out emphasises the necessity of examining not only inherent propensities, if these exist, and the sociopolitical particularities of warfare in Maori society, but also contextual influences in demography and environment that vary on centennial or larger scales. Lastly, the archaeology of Maori warfare, including but not exclusively of the $p a$ sites, is in great need of sustained attention for, in the final analysis, it must be the arbiter of our hypotheses.

\section{References}

Anderson, A.J. 2001. Mobility models of Lapita migration. In G.R. Clark, A.J. Anderson and T. Vunidilo (eds), The archaeology of Lapita dispersal in Oceania, pp. 15-23. Terra Australis 17. The Australian National University, Canberra.

Anderson, A.J. 2006. Islands of exile: Ideological motivation in maritime migration. Journal of Island and Coastal Archaeology 1:33-48. doi.org/10.1080/15564890600579858.

Anderson, A.J. 2013. Patterns and processes of migration in Maori tradition. Biennial Te Rangikaheke Memorial Lecture to the New Zealand History Association Conference, Otakou Marae.

Anderson, A.J. 2014. Monumentality and ritual behaviour in South Polynesia. In H. Martinsson-Wallin and T. Thomas (eds), Studies in global archaeology 24, pp. 273-296, University of Uppsala, Uppsala.

Anderson, A.J. 2016. The making of the Maori middle ages. Journal of New Zealand Studies NS23:2-18.

Anderson, A.J. 2017. Using numbers from somewhere else: Comment on New Zealand numbers from nearly nowhere: 80,000 to 100,000 Maori circa 1769. New Zealand Journal of History 51:122-125.

Anderson, A.J., J. Binney and A. Harris 2014. Tangata Whenua: An illustrated history. Bridget Williams Books, Wellington.

Armit, I. 2011. Violence and society in the deep human past. British Journal of Criminology 51:499-517. doi.org/10.1093/bjc/azq076.

Ballara, A. 1998. Iwi: The dynamics of Maori tribal organization from c. 1769 to c. 1945 . Victoria University Press, Wellington.

Ballara, A. 2003. Taua: 'Musket wars', 'land wars' or tikanga? Warfare in Maori society in the early nineteenth century. Penguin, Auckland. 
Beaglehole, J.C. (ed.) 1961. The journals of Captain James Cook on his voyages of discovery. Volume II: The voyage of the Resolution and Adventure, 1772-1775. The Hakluyt Society, Cambridge.

Beaglehole, J.C. (ed.) 1962. The Endeavour journal of Joseph Banks, Volume II. Angus and Robertson, Sydney.

Beaglehole, J.C. (ed.) 1967. The journals of Captain James Cook on his voyages of discovery. Volume III: The voyage of the Resolution and Discovery, 1776-1780. The Hakluyt Society, Cambridge. doi.org/ $10.4324 / 9781315086149$.

Berns, G.S. and S. Atran 2012. The biology of culture conflict. Philosophical Transactions of the Royal Society B 367:633-639.

Bevan, A., S. Colledge, D. Fuller, R. Fyfe, S. Shennan and C. Stevens 2017. Holocene fluctuations in human population demonstrate repeated links to food production and climate. Proceedings of the National Academy of Sciences USA 114:E10524-E10531. doi.org/10.1073/pnas.1709190114.

Brown, A.A. and E.R. Crema 2019. Maori population growth in pre-contact New Zealand: Regional population dynamics inferred from summed probability distributions of radiocarbon dates. Journal of Island and Coastal Archaeology. doi.org/10.1080/15564894.2019.1605429.

Burtsev, M.S. and A. Korotayev 2004. An evolutionary agent-based model of pre-state warfare patterns: Cross-cultural tests. World Cultures 15:28-36.

Carman, J. and A. Harding (eds) 1999. Ancient warfare: Archaeological perspectives. The History Press, Stroud.

Chapple, S. 2017. New Zealand numbers from nearly nowhere: 80,000 to 100,000 Maori circa 1769. New Zealand Journal of History 51:104-121.

Crampton, P. and C. Parkin 2007. Warrior genes and risk-taking science. New Zealand Medical Journal 120(1250):U2439.

Crosby, R.D. 1999. The musket wars: A history of inter-iwi conflict 1806-45. Reed, Auckland.

Darwin, C. 1909. Voyage of the Beagle. Collier, New York.

Dye, T.S. 2016. Long-term rhythms in the development of Hawaiian social stratification. Journal of Archaeological Science 71:1-9. doi.org/10.1016/j.jas.2016.05.006.

Elder, R.J. 1932. The letters and journals of Samuel Marsden 1765-1838. Coulls Somerville Wilkie and Reed, Dunedin.

Ember, C.R., T.A. Adem and I. Skoggard 2013. Risk, uncertainty and violence in eastern Africa, a regional comparison. Human Nature 24:33-58. doi.org/10.1007/s12110-012-9157-5.

Fenner, J.N. 2005. Cross-cultural estimation of the human generation interval for use in genetics-based population divergence studies. American Journal of Physical Anthropology 128:415-423. doi.org/ 10.1002/ajpa.20188.

Ferguson, R.B. 2008. Ten points on war. Social Analysis 52:32-49.

Ferguson, R.B. and N.L. Whitehead 1992. The violent edge of empire. In R.B. Ferguson and N.L. Whitehead (eds), War in the tribal zone: Expanding states and indigenous warfare, pp. 1-30. School of American Research Press, Santa Fe.

Fitzpatrick, J. 2007. The Columbian exchange and the two colonizations of Aotearoa New Zealand. Food, Culture and Society 10:211-238. doi.org/10.2752/155280107x211421. 
Fry, D.P. and P. Söderberg 2013. Lethal aggression in mobile forager bands and implications for the origins of war. Science 34:270-273. doi.org/10.1126/science.1235675.

Gat, A. 2015. Proving communal warfare among hunter-gatherers: The quasi-Rousseauan error. Evolutionary Anthropology 24:111-126. doi.org/10.1002/evan.21446.

Glowacki, L. and R. Wrangham 2015. Warfare and reproductive success in a tribal population. Proceedings of the National Academy of Sciences USA 112:348-353. doi.org/10.1073/pnas.14122 87112 .

Grey, Sir G. 1954 (1855). Polynesian mythology. First published 1855. Whitcombe and Tombs, Christchurch.

Hall, D., M. Green, G. Chambers and R. Lea 2006. Tracking the evolutionary history of the warrior gene in the South Pacific. Unpublished paper presented at the 11th International Human Genetics Meeting, Brisbane, 6-10 August.

Hook, G.R. 2009. 'Warrior genes' and the disease of being Maori. MAI Review 2009(2).

Houghton, P. 1980. The first New Zealanders. Hodder and Stoughton, Auckland.

Irwin, G.J. 1985. Land, pā and polity: A study based on the Maori fortifications of Pouto. New Zealand Archaeological Association Monograph 15. New Zealand Archaeological Association, Auckland.

Irwin, G.J. 2013. Wetland archaeology and the study of late Maori settlement patterns and social organization in northern New Zealand. Journal of the Polynesian Society 122:311-332. doi.org/ 10.15286/jps.122.4.311-332.

Jones, P., H. Te and B. Biggs 1995. Nga Iwi o Tainui: The traditional history of the Tainui people. Auckland University Press, Auckland.

Keeley, L.H. 2016. Food for war, war for food and war on food. In A.M. VanDerwarker and G.D. Wilson (eds), The archaeology of food and warfare, pp. 291-302. Springer, New York. doi.org/10.1007/978-3319-18506-4_13.

Lagerlöf, N.-P. 2009. Slavery and other property rights. The Review of Economic Studies 76:319-342.

Lea, R. and G. Chambers 2007. Monoamine oxidase, addiction, and the 'warrior' gene hypothesis. New Zealand Medical Journal 20(1250):U2439.

Lehmann, L. and M. Feldman 2008. War and the evolution of belligerence and bravery. Proceedings of the Royal Society B 275:2877-2885. doi.org/10.1098/rspb.2008.0842.

McDermott, R., D. Tingley, J. Cowden, G. Frazzetto and D. Johnson 2009. Monoamine oxidase A gene (MAOA) predicts behavioral aggression following provocation. Proceedings of the National Academy of Sciences USA 106:2118-2123. doi.org/10.1073/pnas.0808376106.

McDonald, M.M., C.D. Navarrete and M. van Vugt 2012. Evolution and the psychology of intergroup conflict: The male warrior hypothesis. Philosophical Transactions of the Royal Society B 367:670-679. doi.org/10.1098/rstb.2011.0301.

McNab, R. 1914. Historical records of New Zealand. Volume II. Government Printer, Wellington.

Merriman, T. and V. Cameron 2007. Risk-taking: Behind the warrior gene story. New Zealand Medical Journal 120(1250):U2440.

Nicholas, J.L. 1817. Narrative of a voyage to New Zealand: Performed in the Years 1814 and 1815 in company with the Rev. Samuel Marsden. Black, London. doi.org/10.1017/CBO9780511707001. 
O’Brien, K. 1993. Between enlightenment and stadial history: William Robertson on the history of Europe. Journal of Eighteenth-Century Studies 16:53-64. doi.org/10.1111/j.1754-0208.1993.tb00155.x.

O'Driscoll, J. 2017. Hillforts in prehistoric Ireland: A costly display of power? World Archaeology 49(4):506-525. doi.org/10.1080/00438243.2017.1282379.

Perbal, L. 2013. The 'warrior gene' and the Maori people: The responsibility of the geneticists. Bioethics 27:382-387. doi.org/10.1111/j.1467-8519.2012.01970.x.

Petrie, H. 2015. Outcasts of the gods: The struggle over slavery in Maori New Zealand. Auckland University Press, Auckland.

Prickett, N.J. 1982. Maori fortifications of the Tataraimaka District, Taranaki. Records of the Auckland Institute and Museum 19:1-52.

Prickett, N.J. 1983. Maori fortifications of the Okato District, Taranaki, Records of the Auckland Institute and Museum 20:1-39.

Roscoe, P.B. 1993. Practice and political centralization: A new approach to political evolution. Current Anthropology 34:111-140.

Roscoe, P. 2016. War and the food quest in small-scale societies: Settlement-pattern formation in contact era New Guinea. In A.M. VanDerwarker and G.D. Wilson (eds), The archaeology of food and warfare, pp. 13-39. Springer, New York. doi.org/10.1007/978-3-319-18506-4_2.

Schmidt, M. 1996. The commencement of pa construction in New Zealand prehistory. Journal of the Polynesian Society 105:441-451.

Skinner, H.D. 1974. Comparatively speaking: Studies in Pacific material culture 1921-1972. Otago University Press, Dunedin.

Smith, C. 2009. The Scottish Enlightenment, unintended consequences and the science of man. Journal of Scottish Philosophy 7:9-28.

Tau, T. M. and A.J. Anderson (eds) 2008. Ngai Tahu: A migration history. The Carrington text. Bridget Williams Books, Wellington.

Thomas, N., H. Guest and M. Dettelbach (eds) 1996. Observations made during a voyage around the world: Johann Reinhold Forster. University of Hawai' i Press, Honolulu.

Thompson, C.A. 1997. A dangerous people whose only occupation is war: Maori and Pakeha in 19th century New Zealand. The Journal of Pacific History 32:109-119. doi. org/10.1080/00223349708572831.

Thorpe, I.J.N. 2003. Anthropology, archaeology, and the origin of warfare. World Archaeology 35:145-165. doi.org/10.1080/0043824032000079198.

Turchin, P. 2011. Toward cliodynamics—an analytical, predictive science of history. Cliodynamics 2:167186. doi.org/10.21237/c7clio21210.

Turchin, P. and A.V. Korotayev 2006. Population dynamics and internal warfare: A reconsideration. Social Evolution and History 5:112-147.

Turner, M. 2004. Functional and technological explanations for the variation amongst early New Zealand adzes. New Zealand Journal of Archaeology 26:57-101.

Vayda, A.P. 1960. Maori warfare. Polynesian Society Maori Monograph 2. Polynesian Society, Wellington. 
Vayda, A.P. 1970. Maoris and muskets in New Zealand: Disruption of a war system. Political Science Quarterly 85(4):560-584. doi.org/10.2307/2147596.

Vayda, A.P. 1974. Warfare in ecological perspective. Annual Review of Ecological Systems 5:183-193.

Von Uexkull, N., M. Croicu, H. Fjelde and H. Buhaug 2016. Civil conflict sensitivity to growing-season drought. Proceedings of the National Academy of Sciences USA 113:12391-12396. doi.org/10.1073/ pnas. 1607542113 .

Whyte, A., S. Marshall and G. Chambers 2005. Human evolution in Polynesia. Human Biology 77:157177. doi.org/10.1353/hub.2005.0045.

Wilson, G.D. and A.M. VanDerwarker 2016. Toward an archaeology of food and warfare.

In A.M. VanDerwarker and G.D. Wilson (eds), The archaeology of food and warfare, pp. 1-12. Springer, New York. doi.org/10.1007/978-3-319-18506-4_1.

Wright, H. 1959. New Zealand, 1769-1840: Early years of western contact. Harvard University Press, Cambridge Massachusetts.

Wright, M. 2011. Guns and Utu: A short history of the musket wars. Penguin, Auckland.

Zhang, D.D., P. Brecke, H.F. Lee, Y.-Q. He and J. Zhang 2007. Global climate change, war, and population decline in recent human history. Proceedings of the National Academy of Sciences USA 104:19214-19219. doi.org/10.1073/pnas.0703073104. 
This text is taken from Archaeological Perspectives on Conflict and Warfare in Australia and the Pacific, edited by Geoffrey Clark and Mirani Litster, published 2022 by ANU Press, The Australian National University, Canberra, Australia.

doi.org/10.22459/TA54.2021.02 